\title{
The Devil Burns Gold There: The Heritage of Nazi Germany Crimes in Death Valley, Chojnice, Poland
}

\author{
Dawid Kobiałka ${ }^{1}$ (D)
}

Accepted: 18 March 2021 / Published online: 26 April 2021

(C) The Author(s) 2021

\begin{abstract}
This paper is about Death Valley - a site of mass killings orchestrated by Nazi Germany that took place on the outskirts of Chojnice during the Second World War. I begin by referring to some examples of conflict archaeology that persuasively demonstrate how what has so far been the domain of history is transforming into archaeology. I then present historical information concerning Death Valley. Following this, the paper presents the results of archaeological investigations into material traces of mass killings in Death Valley. Finally, I present an ethnography of Death Valley, scrutinizing the contemporary role of the site among local communities.
\end{abstract}

Keywords Nazi Germany · Pomeranian crime of $1939 \cdot$ Genocide $\cdot$ Second World War · Poland

\section{Introduction}

Over the past two decades, modern conflict archaeology has rapidly become a vivid, dynamic, and important part of archaeological research and discourse (e.g., Saunders 2007; Schofield 2005). Artifacts and whole landscapes from the First and Second World Wars and the Cold War are now widely recognized as archaeologically relevant and valuable (e.g., Hanson 2016; Kiarszys 2019; Kobiałka 2019). In particular, since the beginning of the twenty-first century, modern conflict archaeology has been attracting new practitioners in Poland (Kiarszys 2019; Ławrynowicz and Żelazko 2015; Mik and Węglińska 2019; Zalewska 2016, 2019). A turning point in Poland was the ground-breaking research of Andrzej Kola (2005) concerning the socalled "Katyn massacre," in which a Soviet NKWD murdered approximately 22,000

Dawid Kobiałka

dawidkobialka@wp.pl

1 Department of Interdisciplinary Archaeological Research, Institute of Archaeology and Ethnography of the Polish Academy of Sciences, Al. Solidarności 105, 00-140 Warsaw, Poland 
Polish citizens (also see Głosek 2004). The remains of some of the victims were exhumed by a research team led by Kola.

The abundance of oral, visual, and written records concerning military conflicts during the twentieth century should not be taken to exclude the value of archaeology in helping to reconstruct the past in its full diversity, complexity and multivocality. Indeed, the foundation of modern conflict archaeology is precisely that oral, visual, and written sources do not tell the whole story (González-Ruibal 2019). As was concisely claimed by Caroline Sturdy Colls (2015:343-344), apropos of her studies within Holocaust archaeologies:

the need to move away from the notion that historical sources can, and have, taught us everything there is to know about the Holocaust. ... Archaeological research has the potential to both complement and supplement existing histories of this period; in some cases, it will act to reaffirm historical accounts, in others, it will reveal information that cannot be derived from documentary evidence; on occasion, it may completely alter historical perception, whilst in other instances, it will add to knowledge about a particular aspect. Whatever the result, it is not conducive for history and archaeology to be viewed as being competing disciplines; each informs the other.

Archaeological field research carried out in Poland during the last two decades underlines this argument: for example, investigations of prisoner of war or concentration camps (Karski et al. 2017; Kobiałka et al. 2017), battlefields that existed between the Rawka and Bzura rivers during the First World War (Zalewska 2019) and secret Soviet nuclear bases hidden in Polish forests during the Cold War (Kiarszys 2019) allow us to sketch a more complex and diverse picture of the (allegedly) well-known recent past. As noted by Saunders (2007: 24), what has usually been the object of historical research is becoming part of (modern conflict) archaeology: history is transforming into archaeology. With respect to the Second World War, "forensic archaeology" is fast developing as a means of collecting, documenting and analyzing the evidence of war crimes (e.g., Anstett and Dreyfus 2015; Ferrándiz and Robben 2015; Godzień 2017; Groen et al. 2015; Sturdy Colls 2015; Trzciński 2013). It is no coincidence that Kola (2005) has defined his research as an archaeology of crime (in Polish, archeologia zbrodni).

The scale of Nazi atrocities in the territory of pre-war Poland is one of the reasons that Polish archaeologists have increasingly turned their attention to the material heritage of the Second World War. One of them is Ławrynowicz (2015, in press) who has been documenting the material evidence of Nazi crimes that took place during the autumn of 1939. These were committed during the so-called Inteligenzaktion, an action against the (Polish) intelligentsia. In 1942 the Germans attempted to conceal these acts by exhuming the mass graves and burning the bodies. The official cryptonym of this action was Aktion 1005 (Hoffmann 2008). Material remains from this process were discovered, mapped, and interpreted by Ławrynowicz. He also identified traces of the Polish exhumations that took place after the war. This was the first archaeological study of Inteligenzaktion and Aktion 1005 in Poland. Another archaeological research project concerning the heritage 
of Inteligenzaktion was carried out in 2020 on the northern outskirts of Chojnice, Poland - an area informally known by the present citizens of Chojnice and neighboring villages as "Death Valley" (Kobiałka et al. 2020).

This paper presents preliminary results from new research in Death Valley with the aim of demonstrating how ethnographic and archaeological methods, techniques, and sources can both supplement and complement historical records concerning mass killings orchestrated by Nazi Germany during the Second World War. It begins by reviewing the historical record of the Second World War in Death Valley and its broader historical context. This is followed by an overview of archaeological investigations into material traces of mass killings in the study area. The paper concludes with an ethnographic account of Death Valley that scrutinizes the contemporary role, meaning, and use of the site among local communities.

\section{The Site: A History of Death Valley in Chojnice and Its Broader Historical Context}

Chojnice was part of the pre-war Polish Pomeranian province which divided the Third Reich (so-called Altreich) from Eastern Prussia. Adolf Hitler used to refer to it as the Polnischer Korridor (Polish Corridor) and it was used by the Third Reich as one of the main justifications to invade Poland on September 1, 1939 (Eukomski 2000) - an act which is generally regarded as initiating the Second World War. The province was later incorporated into the Third Reich as Reichsgau Danzig - Westpreussen. Yet the historic significance of this relatively small piece of land, which remains little known outside Poland, is hard to overestimate since it was here, during the first months of autumn of 1939, that the first genocide of Nazi Germany took place. For this very reason, Tomasz Ceran (2018) calls for these events to be named the Pomeranian Crime of 1939.

The politics, terror, and mass killings of Polish citizens in the Pomeranian province during autumn of 1939 have been discussed by (mostly Polish) historians for decades (e.g. Bojarska 1972; Ceran 2018; Jastrzębski and Sziling 1979; Steyer 1967). One of the ways in which the Germans took control of local communities was to enact mass killings of selected Poles, especially those who were labelled as intelligentsia (including priests, teachers, politicians, merchants, members of the Polish Western League, policemen, and border guards). Accordingly, the process was officially labelled Inteligenzaktion (Wardzyńska 2009). Today it is believed that approximately 30,000-35,000 Polish citizens were murdered in the pre-war Pomeranian province during October and November of 1939 alone (Ceran 2018).

However, the bodies of local intelligentsia were not the only ones who were buried in mass graves in order to cover up the evidence. Very often the very same mass graves were used to hide the remains of disabled people who were also murdered within the so-called Aktion T4. According to Nazi ideology, disabled people embodied worthless life, referred to as Vernichtung von lebensunwertem Leben (e.g., Evans 2004). Additionally, members of the local Jewish society were murdered during (as 
it is sometimes called) the Bloody Autumn of 1939 (Bojarska 1972:122-128; Borzyszkowska-Szewczyk and Pletzing 2010).

Mass killings were frequently well-planned and coordinated in advance. Special units of security police and Einsatzgruppen, as well as members of the Gestapo, supervised the process of apprehending, imprisoning, and finally executing people at remote settings in order to avoid any witnesses (e.g., Mazanowska 2017). Local pre-war German minorities were used to pinpoint which of their neighboring Poles should be eliminated first. These minorities were organized into groups called Selbstschutz Westprussen (Ceran 2014; Jastrzębski 1973, 1974; Lasik 2011; Mazanowska and Ceran 2016). This is why the crimes are sometimes also described in the Polish literature as neighbors' crimes - local German participants usually knew their Polish victims well.

One of approximately 400 locations of executions committed by Germans during the first few months of the war in the pre-war Pomeranian province was located on the northern outskirts of Chojnice. It is believed that at least 500 Polish citizens, consisting of local intelligentsia, disabled people from the National Social Welfare Institutions located in Chojnice as well as around 15 members of the local Jewish community, were taken to remote locations and killed in mass executions during October and November 1939. For this reason agricultural fields, meadows, and forested areas where mass killings were taking place were labeled by citizens of Chojnice and neighboring villages as "Death Valley." Describing the crimes after the war, Wojciech Buchholc (1947:27; my translation) stated in a deeply phenomenological way that "a certain terror is winded from these sinister fields."

Although the Germans did their best to avoid anyone witnessing the crimes, some Poles gave eye witness testimonies after the war. One of them, Leon Styp-Rekowski, survived execution in Death Valley (see more in Buchholc 1947; Grochowski 1947; Lorbiecki 2017) while another witness, Antoni Schüelkie, lived close to one of the spots where the executions took place during autumn of 1939. After the war he recollected (Archive 1 (n.d.); my translation):

approximately 500 people were shot in this site [Death Valley - my note]. A car was stopping at the road. From this spot the prisoners were led to previously constructed trenches. They were set up along the trench. Ten men were brought in, guarded by two to three Nazis. The Nazis usually wore military uniforms. Pistols were used during executions. Sometimes the Poles had to undress, sometimes they were shot in clothes. Some of them were shot from back, other times Poles saw the faces of the Germans.

Other witnesses were present at subsequent killings in Death Valley that occurred at the very end of the war. For example, in the second half of January 1945, a witness named Jan Grunt claimed that a column of approximately 600 Polish prisoners was killed in Death Valley and their bodies burned in order to cover up the evidence (Buchholc 1947:70). The witness testified to "a terrible smell of burning" wafting over the town (Buchholc 1947:70; my translation).

The above accounts were gathered by a District Committee for Commemoration of the Victims of Hitler's Crimes in Chojnice. Its main tasks were to gather evidence of the Germans' crimes in the Chojnice district during the Second 
World War and to locate and exhume remains of those buried in mass graves in Death Valley (Buchholc 1947; Grochowski 1947). Exhumations took place in the autumn of 1945. The bodies of just 107 people were discovered, of which 53 were recognized by families and friends. The committee also located a trench where 218 disabled people from the local hospital were murdered, although here the skulls of just 61 of them were exhumed (Fig. 1) with the remainder left in the mass grave. During one of the local searches members of the committee located charred wood and human ashes, but this spot was not exhumed, either in 1945 or thereafter.

While preparing and carrying out field research within the project "An archaeology of Death Valley," one of our primary hypotheses was that the scale and character of German mass killings on the northern outskirts of Chojnice were likely to have left detectable traces in the modern landscape. It followed that a multidisciplinary approach combining the methods, sources, and perspectives of historical, ethnographic, and archaeological enquiry should allow us to discover, document, map, and analyze examples of this heritage. The next two sections provide a glimpse into some of the preliminary results and discoveries.

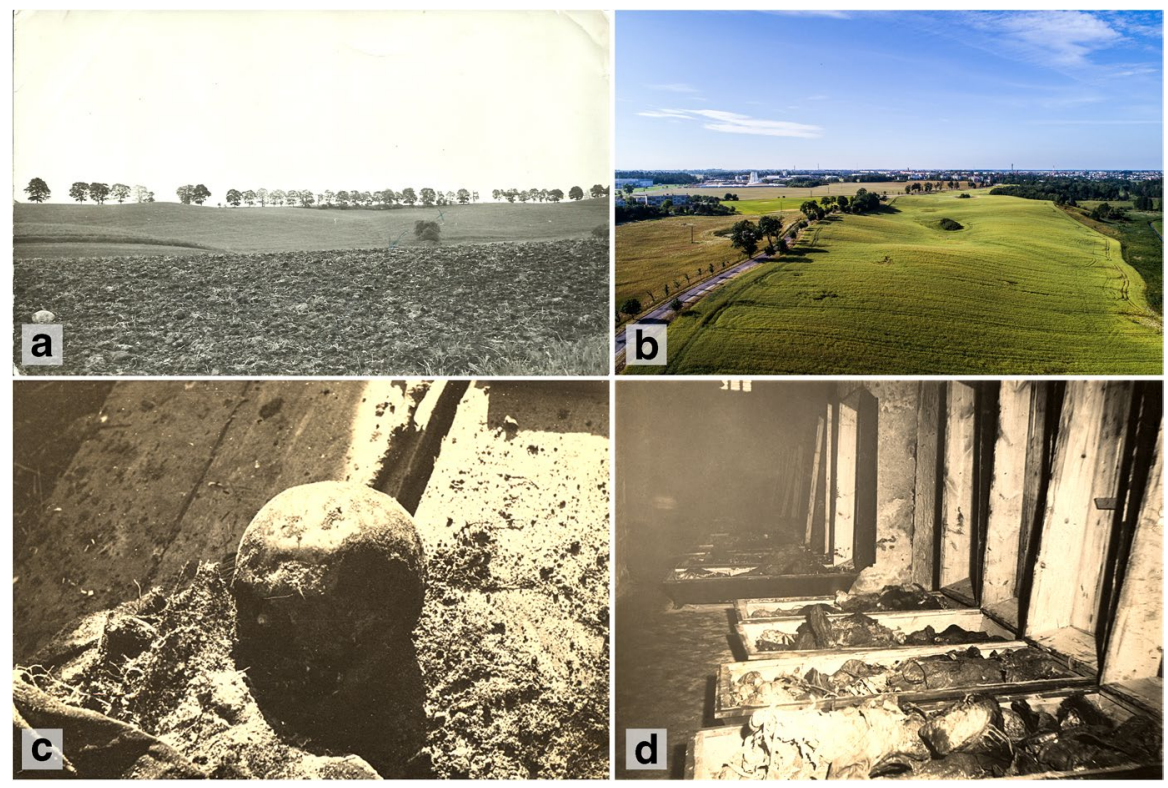

Fig. 1 Heritage of the Nazi Germany crimes in Death Valley in the visual record. a - a view of sinister fields where mass graves were located, a photograph was taken in 1970 (source: Institute of National Remembrance, Poland), b - a contemporary aerial imagery of sinister fields where mass graves were located (author D. Frymark), c - a skull of one of the victims (source: Historical-Ethnographic Museum of Julian Rydzkowski in Chojnice), $\mathbf{d}$ - some of the exhumed bodies in coffins (source: Historical-Ethnographic Museum of Julian Rydzkowski in Chojnice) 


\section{The Site: An Archaeology of Death Valley in Chojnice}

Previous studies had produced neither detailed photographs nor drawings of the mass graves discovered and exhumed in autumn 1945 in Death Valley. Rather, they produced written exhumation reports that describe in detail the number of victims, the state of decay of the bodies, the cause of death, and the personal belongings of the victims. By contrast, any information they contain concerning the location of mass graves is vague and general. Moreover, over the past few decades, little knowledge about the precise spots where exhumations took place has been retained within local communities. It seems that the eight decades since the end of the Second World War were a long enough period of time that memories about the events and their precise locations in the landscape have faded. Saunders (2007) was right: history is transforming into the material and landscape record in front of our eyes, and today it falls to archaeology to discover, map, and analyze the material evidence of the crimes committed during the Second World War.

The witness Schüelkie was one of the persons who testified after the war that trenches prepared by the Polish Army for the war against the Third Reich were reused a few months later as mass graves by the Nazis. These trenches were infilled after the crimes. Since then, local fields where the executions took place have been used for agricultural purposes, and crops such as rape and wheat are still grown there. Today there is little landscape evidence of these trenches to the casual observer. However, through an analysis of LiDAR data and historical aerial images it was possible for us to locate some fragments of them (Fig. 2).

A comparison of a 1940 German aerial photograph (Fig. 2a) with an American image taken at the end of December 1944 (Fig. 2b) provided important information in this respect. In 1940 the area in question was partially a field under crop (black arrow in Fig. 2) and bounded to the north by a meadow (white arrow in Fig. 2). Four years later, however, this former meadow area was partially grown over by bushes while the field remained extensively cultivated (Fig. 2b). We carried out repeat metal detector surveys at both of these locations (along with other parts of Death Valley) (Fig. 3) and these recovered 71 bullets and shell casings from Mauser rifles that were exclusively concentrated in the former meadow area that had become disused and overgrown four years later. It seems therefore that the Germans intentionally left the terrain of mass killings to revert to nature in order to conceal the evidence of their crimes. We also note that information gathered during ethnographic research confirmed that some exhumations in this bushy area were conducted in autumn 1945 (K. J., pers. comm. May 12, 2020).

A paradoxical aspect of the German attempts to conceal the evidence of their crimes in this part of Death Valley is that allowing the area to lie uncultivated and develop scrub vegetation has permitted the area to remain undisturbed since the war. This has discouraged destruction by looters and treasure hunters, and presents an intact 1939 landscape for archaeological field research. During the fieldwork we obtained vital information from one of the respondents who, as a 13-year-old boy in the winter of 1945, reported finding charred wood and human 


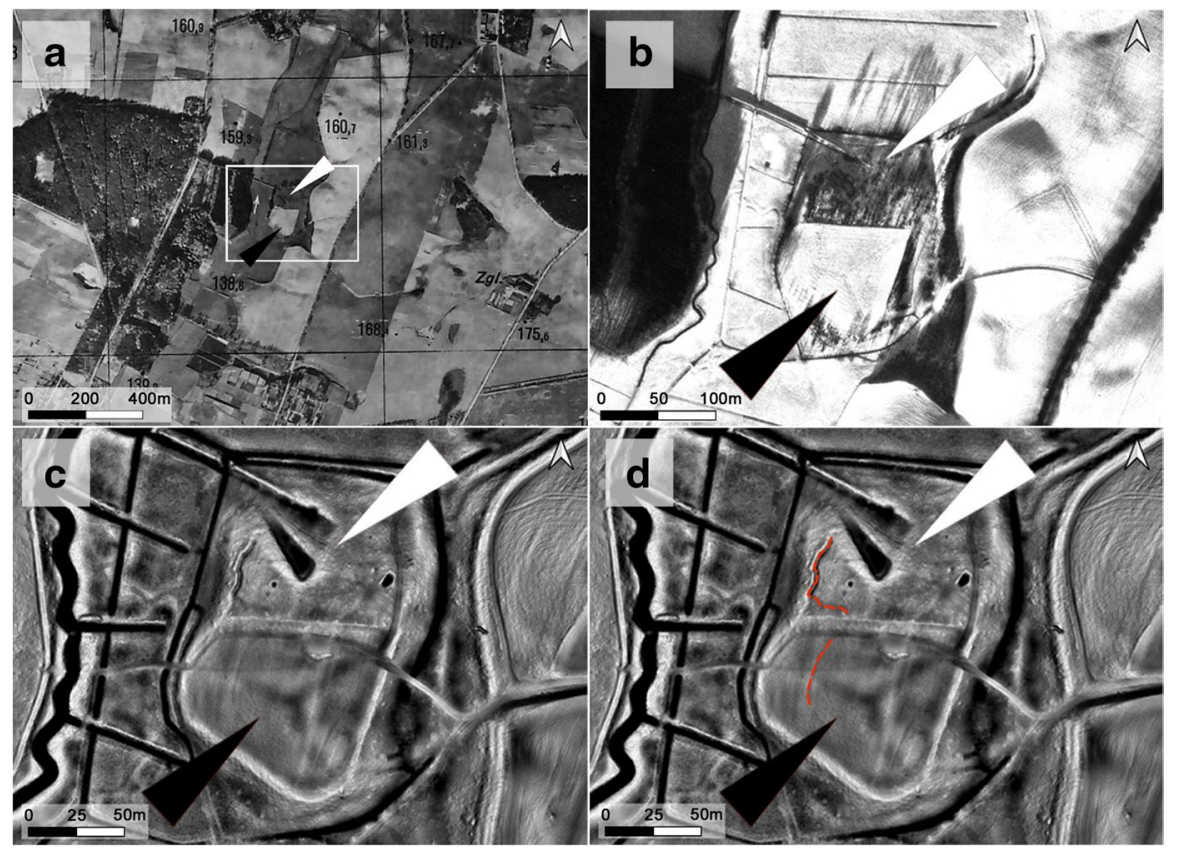

Fig. 2 Trenches dug up by the Polish Army were a few months later reused by Nazi Germans as an ideal place to hide the bodies of the victims. a - an aerial photograph documenting Death Valley in 1940 (source: Bunderarchiv, prepared by M. Kostyrko). White arrow indicates a location where mass killings took place in autumn of 1939. Black arrow indicates a field that was used for agricultural purposes, b - an aerial photograph documenting a fragment of Death Valley in December 1944 (source: National Archives and Records Administrations, USA, prepared by M. Kostyrko), c - a LiDAR derivate documenting a fragment of Death Valley (source: Head Office of Geodesy and Cartography, Poland, prepared by M. Kostyrko), d - an interpretation (dashed line) of LiDAR derivate documenting a fragment of Death Valley with a partially preserved trench (source: Head Office of Geodesy and Cartography, Poland, prepared by M. Kostyrko)

bones in another part of Death Valley. In combination with archival and ethnographic records this helped us to identify an area worthy of special attention and it was here, within a terrain of approximately $20 \mathrm{~m} \times 10 \mathrm{~m}$, that the team discovered and mapped almost 200 artifacts, including bullets and shell casings from German pistols (Walther PPK and P08 Parabellum) (Fig. 4), civil buttons, belt buckles, Polish pre-war coins, fragments of clothes and various personal ornaments that belonged to the victims (Fig. 5). It seems that the crime was committed in a hurry because the artifacts were located just one to $5 \mathrm{~cm}$ below the ground. Among them were fragments of charred wood (Fig. 6) and human ashes (Fig. 7).

This material evidence seems to support the testimony of the aforementioned eye witness Grunt (see above: Buchholc 1947:70). He testified that members of German police units, Gestapo and Hilfswillige (auxiliary units consisting of Ukrainians and deserters from the Red Army) were responsible for the crime. Grunt also noted that a few empty gasoline barrels were found at the site after the war and speculated that 


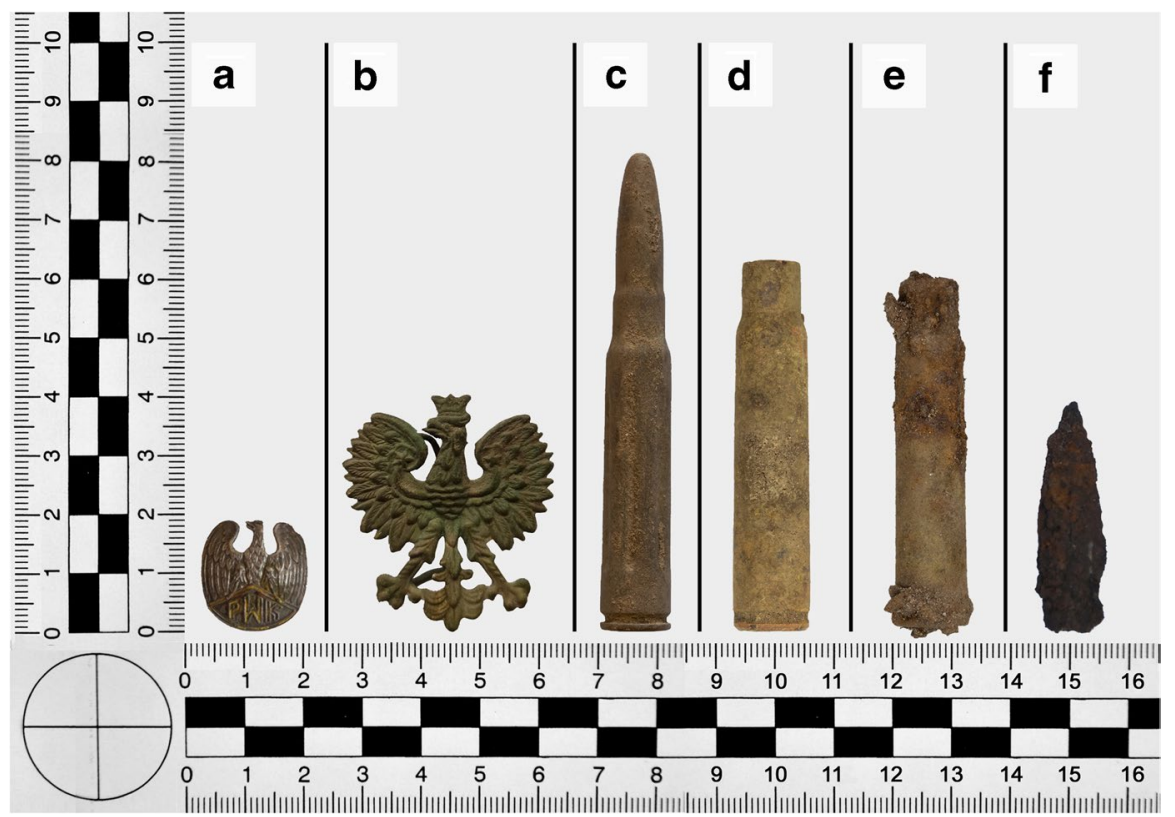

Fig. 3 Material evidence of the crimes committed in autumn of 1939 in Death Valley. $\mathbf{a}$ - a badge of the Female Military Training which was a patriotic organization for women during the time of the Second Polish Republic (1918-39). Germans used to call the members Amazonians and were looking for them during autumn of 1939, b - a badge in form of eagle wz. 27. It was worn on service caps by policemen between 1918-39. Policemen as an embodiment of the reborn Poland were looked for during autumn of 1939 by Germans, $\mathbf{c}$ - a training bullet to a Mauser rifle. The crimes in 1939 were committed mostly by German civilians who did not have experience in using rifles (and murdering people). That is why they were taught by members of Gestapo, among others, how to use a Mauser rifle, d-e - Mauser casing shells found in Death Valley, F - a Mauser bullet found in Death Valley (all photographs D. Kobiałka)

the bodies of the victims were doused in gasoline in order to thoroughly cover up the traces of the mass killing and prevent the later identification of the bodies.

Fig. 4 Material evidence of the crime - bullets and casings shells of German pistols Walther PPK and P08 Parabellum (author D. Kobiałka)

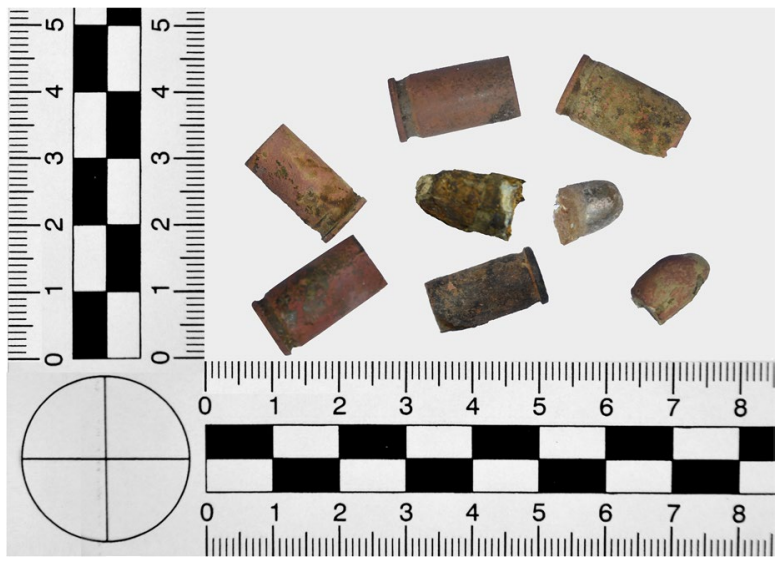




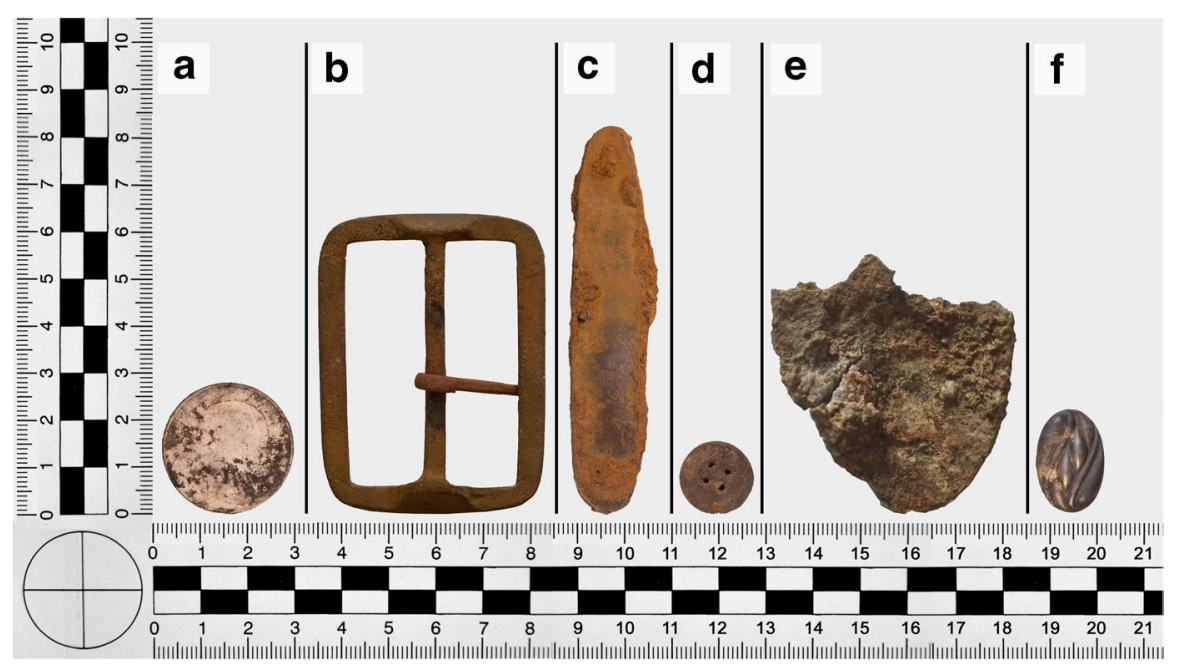

Fig. 5 Material evidence of the crime - some of the personal belongings of the victims. a - a Polish silver pre-war coin - 2 ztote, $\mathbf{b}$ - a Polish military belt buckle wz. 19, c - a pocketknife, $\mathbf{d}$ - a civilian button, $\mathbf{e}-\mathbf{a}$ fragment of burned aluminium spoon, $\mathbf{f}-\mathbf{a}$ fragment of silver brooch. According to the historical records, women were also among the victims (all photographs author D. Frymark)

The material we discovered complement and extend the testimonies of this witness. A plan of the artifacts, charred wood, and human remains suggests that the site of execution was also the spot where a stack was built to burn the bodies. The quantity and financial value of some of the artifacts further suggests that the perpetrators

Fig. 6 Material evidence of the crime - charred fragments of pine (Pinus sylvestris L.) (author J. Rennwanz)

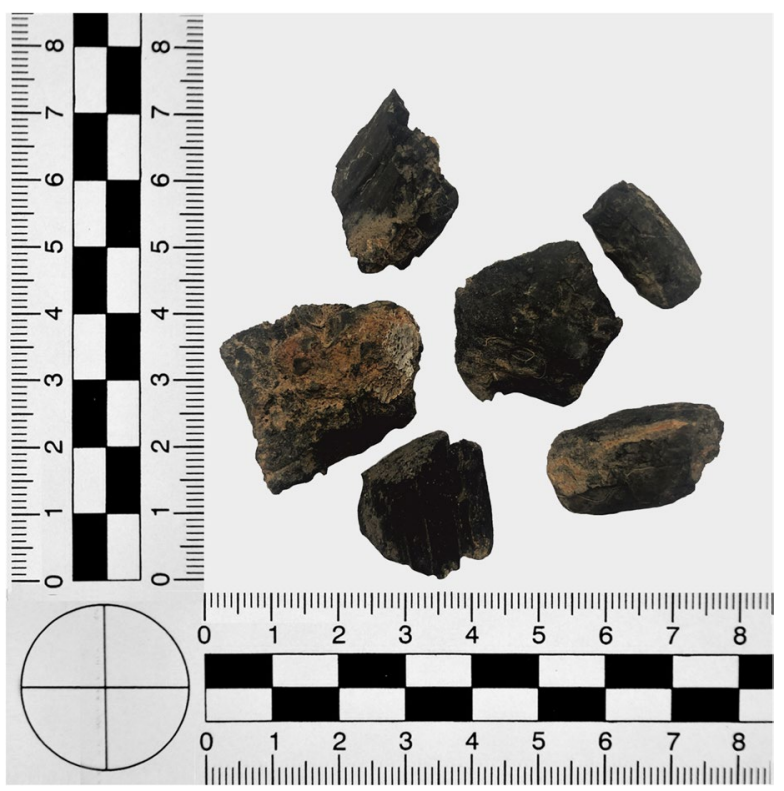




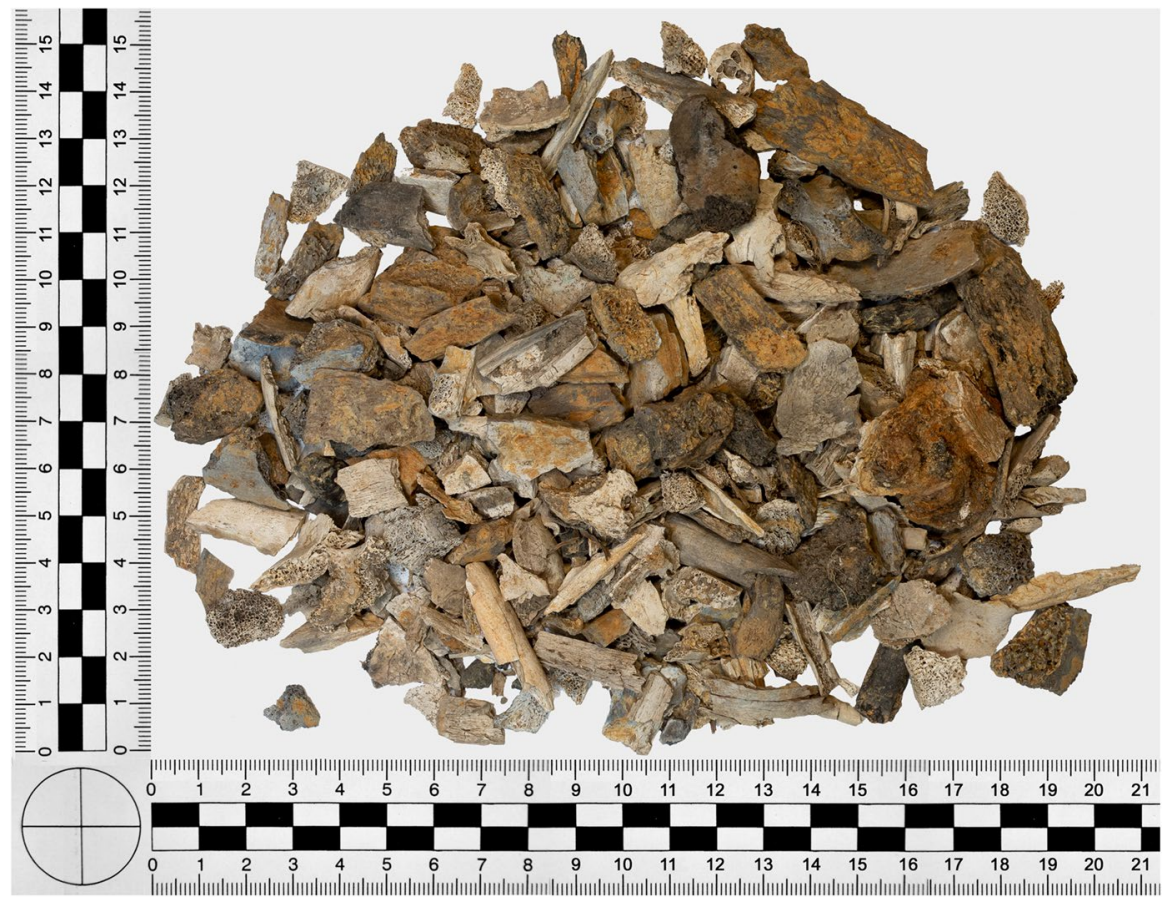

Fig. 7 Material evidence of the crime - burned human bones (author D. Frymark)

did not have time to rob the victims of their valuable personal belongings. Furthermore, all bullets and shell casings discovered at this spot belong to just two kinds of German pistols: the Walther PPK and P08 Parabellum (no shell casing of a Mauser rifle was found at this place). Both pistols were a standard weapon used by various German police units and Gestapo, while a further two shell casings from a Soviet TT pistol are consistent with Grunt's testimony that Hilfswillige units helped carry out the crime. In combination these findings confirm the testimony of Grunt, and it would seem likely that the executions at this site in late January 1945 took the form of a shot from a close distance to the head or back of the victims. After the executions the bodies were thrown on to the cremation stack (Fig. 8).

Additional information that helped us to reconstruct the process of the crime was derived from an analysis of the charred wood that was discovered among the artifacts and human remains (see more in Rennwanz 2020). All of the recovered wood is pine (Pinus sylvestris L.), and yet the Death Valley lies among wet meadows and the local areas of forest do not include pine. Historical maps suggest this was also the case during the Second World War. This would imply that the wood used to build the cremation stack had to be delivered to Death Valley in advance of the executions. A further point is that pine wood was likely a deliberate choice of fuel. It has a high resin content and therefore burns quickly and efficiently, making it perfect for the task of burning something (or someone). We examined the wood under a microscope and found multicolored stains made by oil preserved on its surface. It 


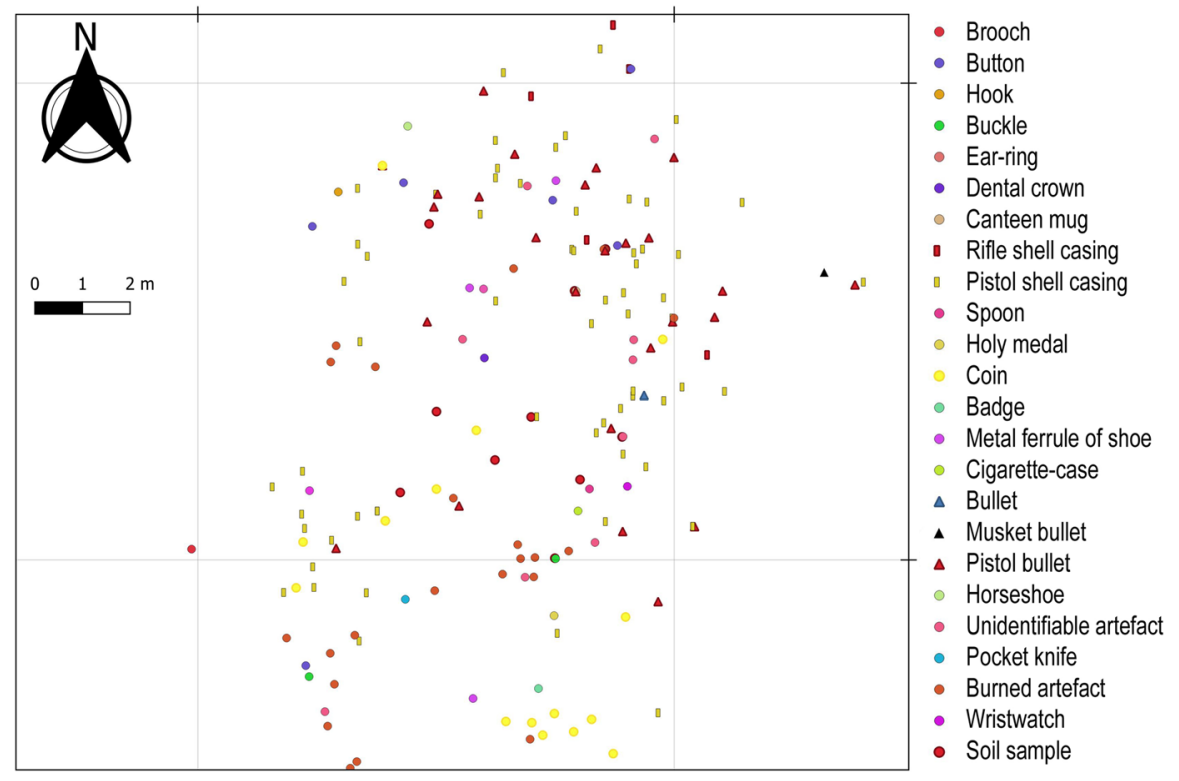

Fig. 8 A planigraphy of artifacts and soil samples at the spot of a crime committed in the second half of January 1945 in Death Valley (prepared by F. Wałdoch)

seems that Grunt's recollections were at least partially correct - the bodies and the stack were doused with oil (not gasoline) to burn the bodies of the victims. Unfortunately, at this moment in the research it must be said that the Nazis were at least partially successful in that the destruction of burned human remains does not enable any detailed anthropological assessment at this moment (Rychtarska 2020). However, the research will be continued and may provide new information after the next season of field research.

A terrifying picture can be drawn from this evidence: although the crime was committed at the very end of the war (Chojnice was liberated on February 14, 1945 by the Red Army), it was well prepared and efficiently committed.

\section{The Site: An Ethnography of Death Valley in Chojnice}

Our work on the history and archaeology of Death Valley has been concerned with the site's past. Our ethnography of Death Valley, on the other hand, aims to scrutinize the various ways in which the role, meaning, and use of the area are manifested in the present. Perhaps the most immediate example is an official monument that commemorates the victims who were murdered in Death Valley. This was erected and publicly exhibited on July 20, 1959 (Fig. 9a), and since that time official ceremonies memorizing the outbreak of the Second World War in Chojnice and the victims killed in the region have taken place on the first day of September each year. At the time of writing, the most recent ceremony occurred on September 1, 2020 
Fig. 9 A memorial in Death Valley. a - a monument erected in 1959 , a photograph was taken in 1970 (source: Institute of National Remembrance, Poland), $\mathbf{b}$ - a contemporary version of commemoration of the victims (author D. Kobiałka)
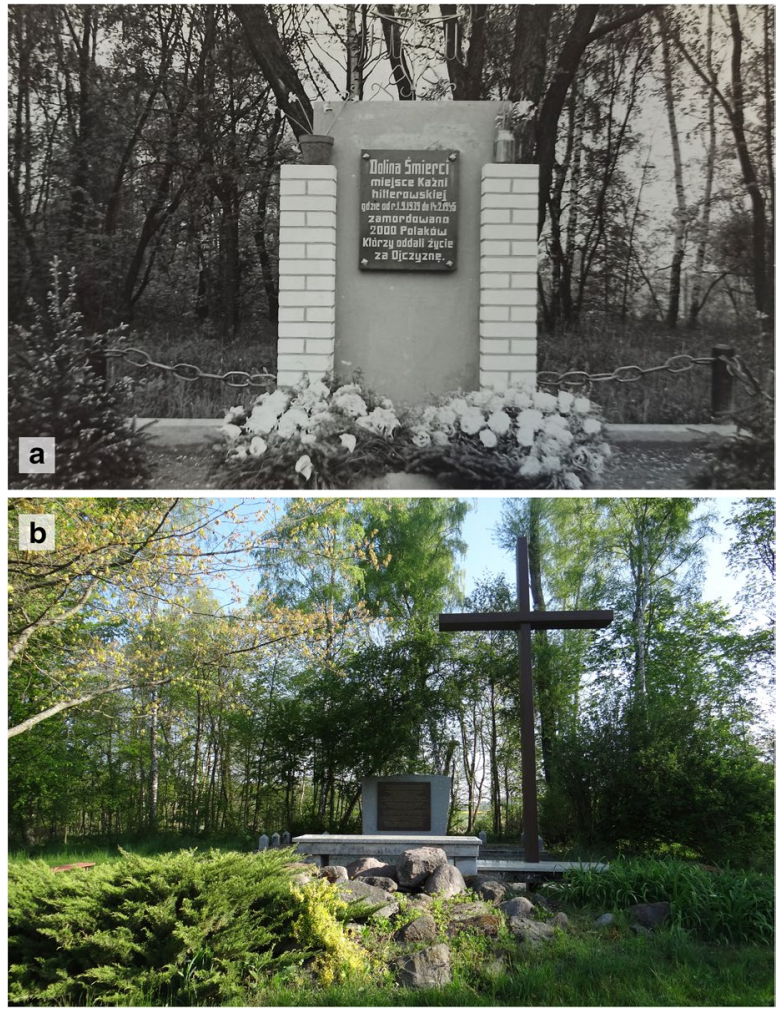

and was an event in which the research team also participated (Fig. 9b). However, many other observations made during field research seemed to suggest that Death Valley may also be considered a "valley of life."

In the first instance it is not surprising that memories of the site and its victims are most vivid among those who lost their fathers, mothers, parents, grandparents, or great grandparents here (Fig. 10). From a historical, archaeological and ethnographic point of view, conversations with the oldest relatives were the most revealing. The oldest interviewee was 95 years old and for her, as for many others, the history of Death Valley is a part of their lives. It is not history in the sense of being something old, dead, and forgotten. Memories of relatives killed on the outskirts of Chojnice are an integral part of their life. These people were also the most curious about the material culture and material evidence of the crimes that were discovered during our archaeological investigations.

During ethnographic research, the team collected many visual, oral, and written documents that have never been published. An interesting case concerns the great grandsons of Józef Kościelny who was murdered in Death Valley on November 11, 1939 (Fig. 11). His great grandsons were not only eager to share their family's memories of their great grandfather with the team: they actively searched for other memories and documents among their broader family that might be of interest to the research. But the exchange of information was not 
Fig. 10 Ethnographic research - recording memories of those who lost their relatives in Death Valley (author D. Frymark)
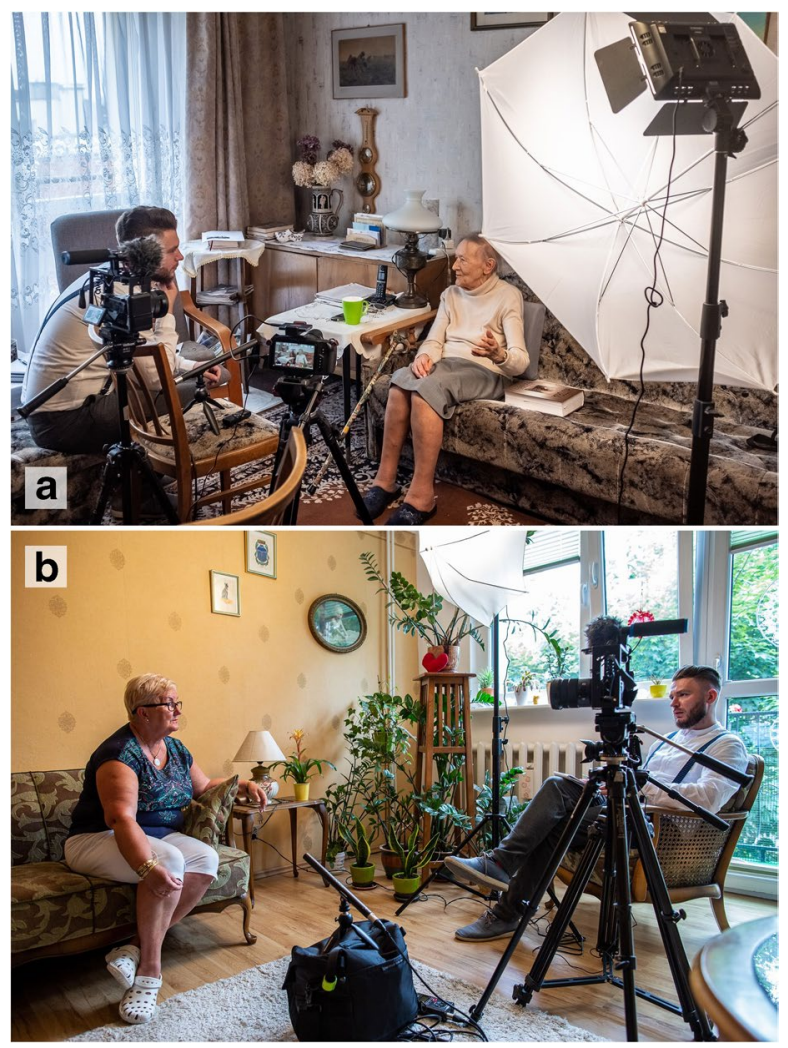

solely one-way since our archival research yielded many testimonies from victims whose relatives were interviewed during the project. These included the great grandsons of Kościelny, and we were able to pass on copies of documents containing the testimonies of Leokadia Kościelna, the wife of Józef Kościelny. As is easy to imagine, this was an emotional and deeply touching experience for the family. While they were seated together, the testimony was read by the mother of the respondents. One of them (R. K., pers. comm. June 16, 2020; my translation) admitted that "While reading it, we simply cried. It is as if great grandmother was standing in front of us and telling the whole story. From an ethnographic point of view, the fact that the great grandsons of Kościelny actively participated in our archaeological field research is also worthy of note. Indeed, they were present when one of the trenches was opened in the spot where it was assumed that their great grandfather was killed, buried in 1939, and exhumed in 1945. Taking part in an excavation means sometimes literally digging for one's family history.

For those relatives of the victims killed in Death Valley the site is an important aspect of life and memorial practices. On the other hand, there are many citizens of contemporary Chojnice who did not lose their parents, grandparents, or great grandparents during the mass killing on the outskirts of the town. The value they attach to 
Fig. 11 Józef Kościelny - one of the victims murdered during autumn of 1939 in Death Valley (R. Kerszk's private archive)

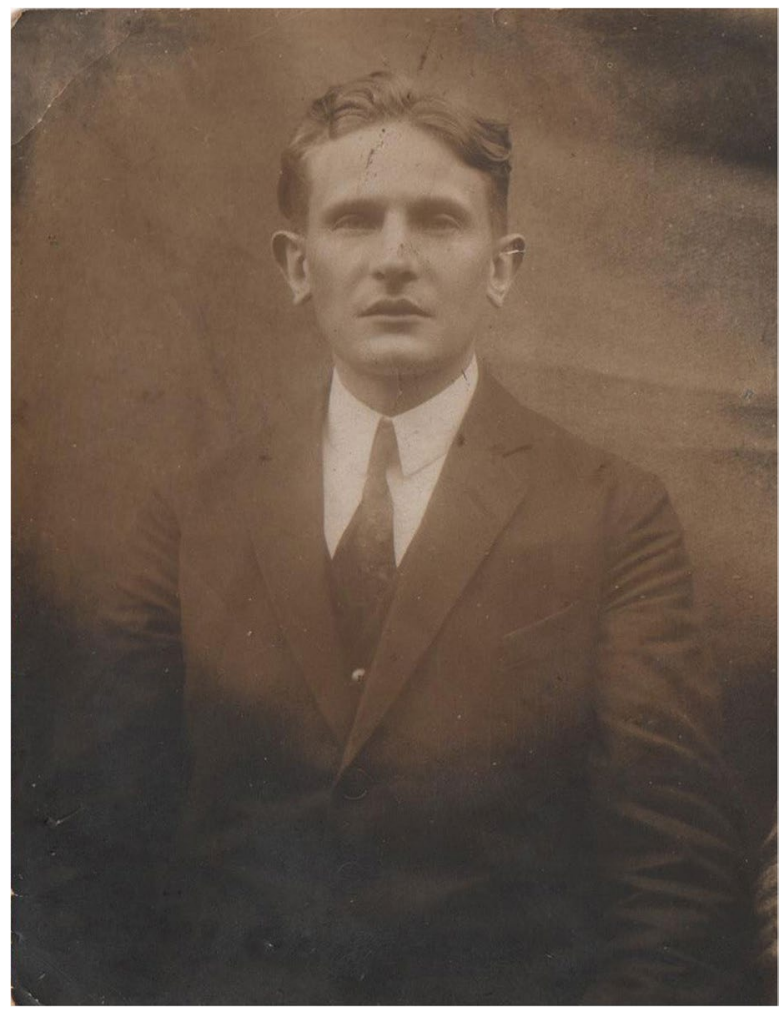

the site and the way the site is used were also the subject of our ethnographic inquiries and our results show that there are many ways in which Death Valley is "alive."

Our first example concerns the aforementioned official ceremonies and a mass that take place in Death Valley on September 1 to commemorate the outbreak of the war and the victims from Chojnice and its neighboring areas who lost their life during the war. The area is prepared in advance for the ceremony. This includes the collection of rubbish (e.g., bottles and cans for beer and vodka) most likely discarded by teenagers who use the location for meetings (and drinking alcohol together). The grass that grows on a contemporary meadow in Death Valley, which was a crop field before and during the war, is cut and cleared to enable people to gather and sit during the mass. The fact that the grass is cut before September 1 means that the grass is unable to grow again before winter. The area around Death Valley is a wetland. Why is this important? It appears that the preparation for annual ceremonies in Death Valley makes the area a perfect habitat for specific kinds of mushrooms - Psilocybe semilanceata L. and Psilocybe mexicana L. (Fig. 12).

These are hallucinogenic mushrooms that are sometimes gathered and eaten by teenagers from Chojnice and are even the object of various exchanges and transactions. During our ethnographic research, a popular memory was recounted among teenagers who live close to Death Valley concerning events a few years ago when one teenager ate so many mushrooms that he was sick and never returned to full 


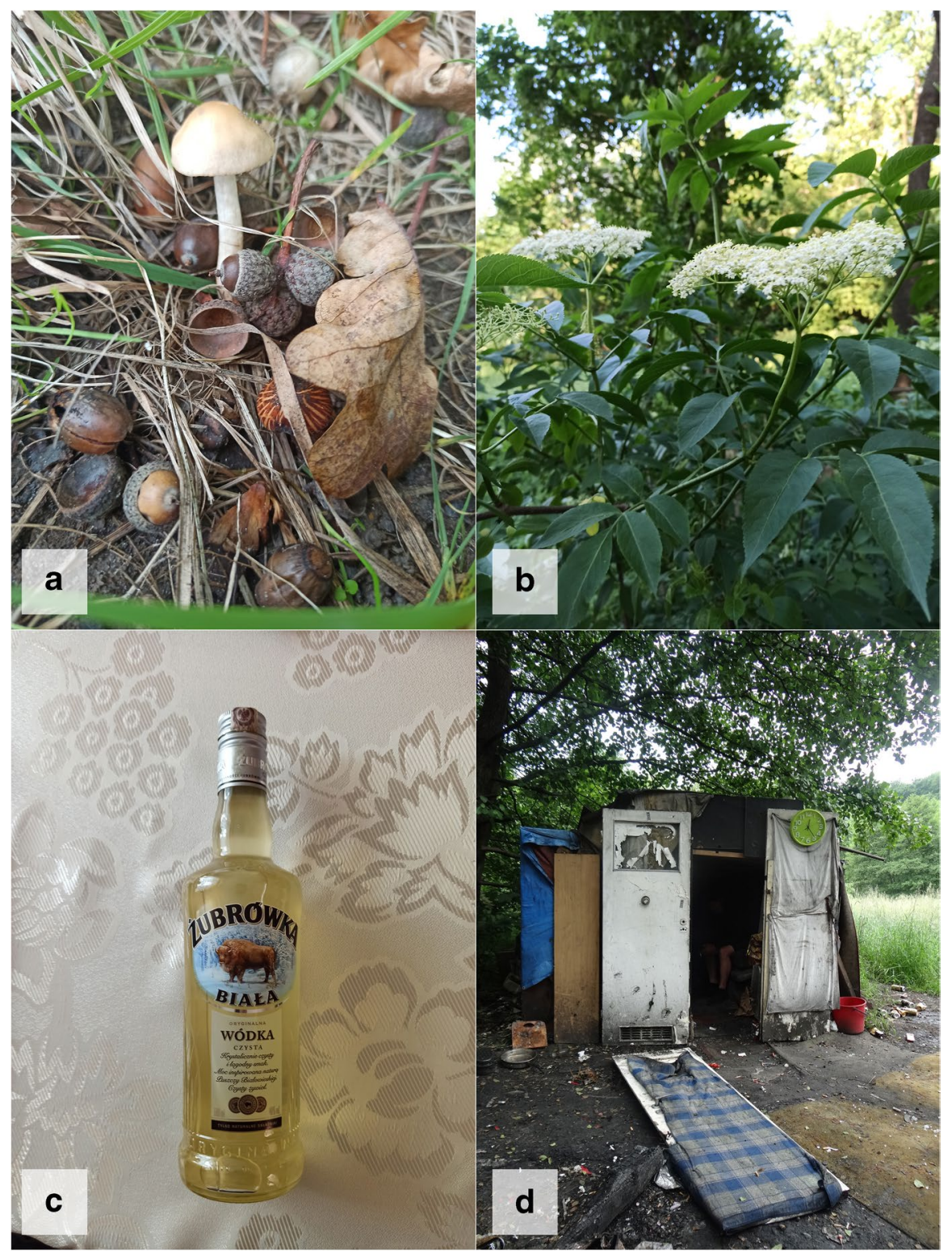

Fig. 12 The use of heritage of Death Valley in the present. $\mathbf{a}$ - a hallucinogenic mushroom documented during field research in Death Valley, $\mathbf{b}$ - flowers of common lilacs documented during field research in Death Valley, $\mathbf{c}$ - an alcoholic liquor made of common sow thistles gathered by one of the respondents and his daughter in Death Valley, $\mathbf{d}-$ a shelter built by homeless people at the vicinity of Death Valley (all photographs author D. Kobiałka)

health. Most of these young people seem to define themselves as patriots, but the goal of their visits to Death Valley during late autumn is not to pay tribute to those who lost their life there. They visit Death Valley to collect hallucinogenic 
mushrooms that almost literally grow over the site of mass graves. Indeed, it must be a unique experience to eat hallucinogenic mushrooms from a site where a few hundred people lost their lives, and at which some of them are still buried.

The second example concerns how locals value the natural heritage of Death Valley and is an unexpected result of the research. The Nazis used nature to cover up the evidence of the crime. Today, teenagers make use of the natural heritage of Death Valley, while older citizens of Chojnice make creative use of this heritage as well. In particular, another interviewee was an 88-year-old man who visited Death Valley during our archaeological research in order to collect the flowers of the common lilac (Syringa vulgaris L.). He knew a great deal about Death Valley and its sinister history. This, however, did not deter him from collecting the flowers from which the informant prepares, as he proudly admitted, "a delicious syrup." The man regularly consumes this syrup and even believes that it is one of the causes of his good shape and health at the age of 88 . However, the flowers were gathered at a spot that could hide one of the undiscovered mass graves from 1939. An assemblage of shell casings and bullets from a Mauser rifle found closely to this bushy area supports this hypothesis.

The third example is the story of K. J., who showed the research team the approximate location of burned human bones he found in December 1945. May in Poland is usually a time when nature comes back to life after winter and during this time the meadow of Death Valley is a colorful and pleasant landscape. It is full of common sow thistles (Sonchus oleraceus L.) which transform the meadow into a yellow carpet. These flowers can be considered another kind of heritage of Death Valley since they are gathered every year by some of the Chojnice citizens (including K. J. and his daughter) for production of an alcoholic liquor. While carrying out an interview with K. J. on May 12, 2020, I was asked if I wanted to try it. Although it is commonly known that eating (and drinking alcohol) with people among whom ethnographic field research is carried out is a good way of bonding and collecting data, the proposition was before 12 a.m. and, unfortunately, I had to decline.

The final ethnographic perspective of Death Valley as a valley of life is the fact that homeless people live on its outskirts. They managed to build a camp for themselves close to the site and on a spot that may be one of the locations of the mass grave where 218 disabled people were killed by the Nazis and who were not exhumed in 1945. Here people literally live upon the dead.

\section{Conclusion}

This paper has discussed some of our preliminary results and reflections from the research we carried out in 2020 on the terrain of Death Valley on the northern outskirts of Chojnice, Poland, where Germans killed a few hundred Polish citizens during the autumn of 1939 and in the second half of 1945. The scale and mass character of the murders during October and November 1939 has prompted some historians to argue that this event should be considered as the first genocide of the Second World War - the Pomeranian Crime of 1939 (Ceran 2018). 
Germans did their best to produce as little as possible in terms of written administrative documents that could later confirm the crimes. Additionally, the mass killings were committed at remote settings to avoid unnecessary witnesses. This is precisely why archaeology is so important and relevant today as a means of discovering, documenting, mapping, and interpreting the manifest heritage of the crimes committed during the Second World War (Sturdy Colls 2015). The history of the Second World War is becoming an archaeology of the Second World War.

The project has applied a multidisciplinary approach that combines methods, techniques, and perspectives specific to history, ethnology, and archaeology and has allowed us to analyse different kinds of heritage related to Death Valley. These explore the past and present value, significance and use of the site and illuminate various ways of engaging with this difficult and still painful heritage.

An analysis of written and visual records related to the crimes that took place in Death Valley was the first step. During archival research we discovered some sources that had never been discussed in the literature. Before organizing archaeological field research it was already known that human remains and material culture left by the perpetrators (e.g., bullets, shell casings) had to be somewhere in Death Valley. Ethnographic research was another and no less relevant step in uncovering them. Memories of those who lost their parents, grandparents, or even great grandparents in Death Valley were recorded. One of the interviewees indicated the place where in 1945 he found a heap of burned bones and charred wood relating to a crime from the second half of January 1945. Ethnographic interviews and participant observation allowed us to document the many ways in which Death Valley functions today among local communities. However, the aspect of the project that dealt with archaeological research was perhaps the most important. Using archaeological methods, artifacts were found in addition to the remains of charred wood and human ashes, and these constitute the material evidence of the crimes committed in Death Valley.

During the ethnographic research one of the respondents admitted that during the 1950s his father was warned by his own parents to not go to Death Valley because "the devil burns gold there" (T. J., pers. comm. May 15, 2020; my translation). This warning can be interpreted as follows: the devil stands for Nazis, gold is a metaphor for a few hundred people who were murdered there, their bodies doused with oil and burned to prevent the later identification of the victims. Metaphorically speaking, what happened at Death Valley was hell on earth.

In conclusion, it can be argued that ethnographic and archaeological investigations in Death Valley are proving a crucially important means of both supplementing and complementing historical records of mass killings by Nazi Germany during the Second World War. It is perhaps ironic that German attempts to hide the evidence of their crimes has so effectively enabled the various types of material culture to be preserved until the present.

Acknowledgments Many people helped me during the research. I would like to thank Mikołaj Kostyrko, Filip Wałdoch, Katarzyna Kość-Ryżko, Ewelina Ebertowska, Marta Rychtarska, Agnieszka Banaszak, Joanna Rennwanz, Daniel Nita, Robert Ryndziewicz, Marta Rychtarska, Zbigniew Kubiatkowski, and Daniel Frymark for help during the realization of the project. A big thank to my wife Anna Kobiałka who graphically refined figures to this article. Finally, I thank two anonymous reviewers for 
their careful reading of the manuscript and their many insightful comments and suggestions. However, I remain entirely responsible for any simplifications and errors.

This project was financed by the Ministry of Culture and National Heritage, Poland (02359/20/FPK/ DDK).

\section{Declarations}

Conflict of Interest The author declares that he has no conflict of interest.

Open Access This article is licensed under a Creative Commons Attribution 4.0 International License, which permits use, sharing, adaptation, distribution and reproduction in any medium or format, as long as you give appropriate credit to the original author(s) and the source, provide a link to the Creative Commons licence, and indicate if changes were made. The images or other third party material in this article are included in the article's Creative Commons licence, unless indicated otherwise in a credit line to the material. If material is not included in the article's Creative Commons licence and your intended use is not permitted by statutory regulation or exceeds the permitted use, you will need to obtain permission directly from the copyright holder. To view a copy of this licence, visit http://creativecommons.org/licen ses/by/4.0/.

\section{References}

Anstett, E. and Dreyfus, J.-M. (eds.) (2015). Mass Violence, Genocide and the “Forensic Turn." Manchester University Press, Manchester.

Archive 1 (n.d.). Okręgowa Komisja Badania Zbrodni Niemieckich w Bydgoszczy - Odziat Okręgu w Chojnicach (akta nr 6/2437/3). Archiwum Państwowe w Bydgoszczy.

Bojarska, B. (1972). Eksterminacja Inteligencji Polskiej na Pomorzu Gdańskim (Wrzesień-Grudzień 1939). Instytut Zachodni, Poznań.

Borzyszkowska-Szewczyk, M. and Pletzing, Ch. (2010). Chojnice. In Borzyszkowska-Szewczyk, M. and Pletzing, C. (eds.), Śladami Żydowskimi po Kaszubach. Przewodnik, Academia Baltica, GdańskLübeck-München, pp. 188-192.

Buchholc, W. (1947). Chojnice w latach 1939-1945. In Chojnice 1939-1945, Powiatowy Komitet Uczczenia Ofiar Zbrodni Hitlerowskich w Chojnicach, Chojnice, pp. 12-159.

Ceran, T. S. (2014). Im Namen des Führers... Selbstschutz. Westpreussen i Zbrodnia w Lopatkach $w 1939$ roku. Instytut Pamięci Narodowej - Komisja Ścigania Zbrodni przeciwko Narodowi Polskiemu, Bydgoszcz-Gdańsk.

Ceran, T. S. (2018). The Pomeranian Crime 1939. Institute of National Remembrance - Commission for the Prosecution of Crimes Against the Polish Nation, Warsaw.

Evans, S. E. (2004). Forgotten Crimes: The Holocaust and Disabled People. Ivan R. Dee, Chicago.

Ferrándiz, F. and Robben, A. (eds.) (2015). Mass Graves and Exhumations in the Age of Human Rights. University of Pennsylvania Press, Philadelphia.

Głosek, M. (ed.) (2004). Katyń w Świetle Badań Terenowych, 1994-1995. Dom Wydawniczy Duet, Toruń.

Godzień, A. (2017). Archeologia Sadowa: Zarys Problematyki. Oficyna Wydawnicza “Zimowit,” Rzeszów.

González-Ruibal, A. (2019). An Archaeology of the Contemporary Era. Routledge, London.

Grochowski, M. (1947). Ku czci męczenników. In Chojnice 1939-1945, Powiatowy Komitet Uczczenia Ofiar Zbrodni Hitlerowskich w Chojnicach, Chojnice, pp. 3-11.

Groen, W. J. M., Márquez-Grant, N., and Janaway, R. (eds.) (2015). Forensic Archaeology: A Global Perspective. Wiley-Blackwell, London.

Hanson, T. A. (2016). The Archaeology of the Cold War. University Press of Florida, Gainesville.

Hoffmann, J. (2008). Das kann man nicht erzählen. "Aktion 1005” - Wie die Nazis die Spuren ihrer Massenmorde in Osteuropa beseitigen. Konkret Literaturverlag, Hamburg.

Jastrzębski, W. (1973). Zbrodnie Selbstschutzu na ludności polskiej i żydowskiej powiatu wyrzyskiego popełnione jesienią 1939 roku. Rocznik Nadnotecki 5: 73-89. 
Jastrzębski, W. (1974). Terror i Zbrodnia: Eksterminacja Ludności Polskiej i Żydowskiej w Rejencji Bydgoskiej w Latach 1939-1945. Interpress, Warszawa.

Jastrzębski, W. and Sziling, J. (1979). Okupacja Hitlerowska na Pomorzu Gdańskim w Latach, 19391945. Wydawnictwo Morskie, Gdańsk.

Karski, K., Różycki, S., and Schwarz, A. (2017). Memories of recent past: objectives and results of noninvasive archaeological research project at KL Plaszow memorial site. Analecta Archaeologica Ressoviensia 12: 221-246.

Kiarszys, G. (2019). Atomowi Żotnierze Wolności. Archeologia Magazynów Atomowych w Polsce. Wydawnictwo Naukowe Uniwersytetu Szczecińskiego, Szczecin.

Kobiałka, D. (2019). Living monuments of the Second World War: terrestrial laser scanning and trees with carvings. International Journal of Historical Archaeology 23(1): 129-152.

Kobiałka, D., Kostyrko, M., and Kajda, K. (2017). The Great War and its landscapes between memory and oblivion: the case of prisoners of war camps in Tuchola and Czersk, Poland. International Journal of Historical Archaeology 21(1): 134-151.

Kobiałka, D., Kostyrko, M., Kość-Ryżko, K., Wałdoch, F., Ebertowska, E., Rychtarska, M., Rennwanz, J., Banaszak, A., Ryndziewicz, R., and Kubiatowski, Z. (2020). Archeologia Doliny Śmierci - wstępne wyniki badań terenowych. Zeszyty Chojnickie 34: 112-131.

Kola, A. (2005). Archeologia Zbrodni: Oficerowie Polscy na Cmentarzu Ofiar NKWD w Charkowie. Uniwersytet Mikołaja Kopernika, Rada Ochrony Pamięci Walki i Męczeństwa, Toruń.

Lasik, A. (2011). Selbstschutz na Pomorzu Gdańskim i w Wielkopolsce w latach 1939-1940. Przyczynek do badań nad początkami okupacji niemieckiej Polski w okresie II wojny światowej. In Mietz, A. and Szczepankiewicz, P. (eds.), Studia z Dziejów Pogranicza Kujawsko-Wielkopolskiego t. I, Urząd Gminy w Wierzbinku, Bydgoszcz-Wierzbinek, pp. 101-121.

Lorbiecki, A. (2017). Trzy Cmentarze - Trzy Tablice. Urząd Miejski w Chojnicach, Chojnice.

Ławrynowicz, O. (2015). Niemieckie zbrodnie nazistowskie w lasach podłódzkich. Weryfikacje archeologiczne miejsc pamięci. In Ławrynowicz, O. and Żelazko, J. (eds.), Archeologia Totalitaryzmu. Ślady Represji 1939-1956, Oddziałowa Komisja Badania Zbrodni Przeciwko Narodowi Polskiemu w Łodzi - Instytut Pamięci Narodowej, Instytut Archeologii UŁ, Łódź, pp. 65-94.

Ławrynowicz, O. (in press). Niemieckie Zbrodnie Nazistowskie w Lasach Podłódzkich. Perspektywa Archeologiczna. Instytut Archeologii UŁ, Łódź.

Ławrynowicz, O. and Żelazko, J. (eds.) (2015). Archeologia Totalitaryzmu. Ślady Represji 1939-1956. Oddziałowa Komisja Badania Zbrodni Przeciwko Narodowi Polskiemu w Łodzi - Instytut Pamięci Narodowej, Instytut Archeologii UŁ, Łódź.

Łukomski, G. (2000). Problem "Korytarza" $w$ Stosunkach Polsko-Niemieckich $i$ na Arenie Międzynarodowej, 1919-1939. Studium Polityczne. Oficyna Wydawnicza “Adiutor,” Warszawa.

Mazanowska, I. (2017). Karolewo 1939. Zbrodnie w Obozie Selbstschutz. Westpreussen. Instytut Pamięci Narodowej - Komisja Ścigania Zbrodni przeciwko Narodowi Polskiemu, Gdańsk-Warszawa.

Mazanowska, I. and Ceran, T. S. (eds.) (2016). Zapomniani Kaci Hitlera. Volksdeutscher Selbstschutz w Okupowanej Polsce, 1939-1940. Wybrane Zagadnienia. Instytut Pamięci Narodowej - Komisja Ścigania Zbrodni przeciwko Narodowi Polskiemu, Bydgoszcz-Gdańsk.

Mik, H. and Węglińska, W. (eds.) (2019). Materialne Pozostałości Konfliktów i Zbrodni XX Wieku w Świetle Najnowszych Badań Archeologicznych. Wydawnictwo Muzeum II Wojny Światowej w Gdańsku, Gdańsk.

Rennwanz, J. (2020). Wstępny Raport z Analizy Drewna i Węgli Drzewnych z Odwiertów Archeologicznych $w$ Dolinie Śmierci $w$ Chojnicach (niepublikowany raport w archiwum projektu ,Archeologia Doliny Śmierci”). Instytut Archeologii i Etnologii PAN, Poznań.

Rychtarska, M. (2020). Raport z Realizacji Części Zadania 3 - Analiza Antropologiczna Spalonych Szczatków Kostnych z Doliny Śmierci w Chojnicach (woj. Pomorskie) (niepublikowany raport w archiwum projektu „Archeologia Doliny Śmierci”). Katedra Antropologii Uniwersytetu Przyrodniczego we Wrocławiu, Poznań.

Saunders, N. (2007). Killing Time: Archaeology and the First World War. Sutton, Stroud.

Schofield, J. (2005). Combat Archaeology: Material Culture and Modern Conflict. Duckworth, London.

Steyer, D. (1967). Eksterminacja Ludności Polskiej na Pomorzu Gdańskim w Latach 1939-1945. Wydawnictwo Morskie, Gdynia.

Sturdy Colls, C. (2015). Holocaust Archaeologies: Approaches and Future Directions. Springer, New York. Trzciński, M. (ed.) (2013). Archeologia Sadowa w Teorii i Praktyce. Lex a Wolters Kluwer Business, Warszawa. Wardzyńska, M. (2009). Byt Rok 1939. Operacja Niemieckiej Policji Bezpieczeństwa w Polsce. Intelligenzaktion. Instytut Pamięci Narodowej - Komisja Ścigania Zbrodni przeciwko Narodowi Polskiemu, Warszawa. 
Zalewska, A. (ed.) (2016). Archeologia Wspótczesności. SNAP, Warszawa.

Zalewska, A. (ed.) (2019). Archeologiczne Przywracanie Pamięci o Wielkiej Wojnie w Rejonie Rawki $i$ Bzury. Instytut Archeologii i Etnologii PAN, Warszawa.

Publisher's Note Springer Nature remains neutral with regard to jurisdictional claims in published maps and institutional affiliations. 